\title{
Progress Continuance Sustainability
}

\author{
Rinaldo C. Michelini, Roberto P. Razzoli \\ DIME-Department of Mechanics, Energetics, Management and Transportation, University of Genova, \\ Genova, Italy \\ Email: michelini@dimec.unige.it, razzoli@dimec.unige.it
}

Received 12 November 2015; accepted 25 December 2015; published 28 December 2015

Copyright (C) 2015 by authors and Scientific Research Publishing Inc.

This work is licensed under the Creative Commons Attribution International License (CC BY). http://creativecommons.org/licenses/by/4.0/

cC) (7) Open Access

\begin{abstract}
The "progress" is the outcome of the intentional alteration of the wild surrounds to establish enhanced friendly life conditions for men. The swop entails the earth inhabitants, matching extant peoples by the "social breakthrough", leading to "collective orders" or human civilization political endings. This identifies as the public range relational setup, by which the men enable planned progress, via culture/ethics artifacts, inventing authority, legality and management, to support trade and business, in view of plus-value arrangements. This "social breakthrough" entails hierarchic arts to assign sovereignty rules, with acknowledged leadership. In basic construal, the survey links cosmos' destiny to men's wherewithal, that is, the ability of agentive and rational choice of controlled life-quality behavioural traits occurs because of suited "anthropic principles". The legality arts, on the political endings, here, confine into split-sovereignty outfits.
\end{abstract}

\section{Keywords}

Sustainability, Civilization, Anthropic Principles

\section{Introduction}

When we explore our civilisation, the astonishment is forced to recognise it an absurd fact is that the earth is totally negligible entity, in a universe rather intricate, but without evident concern with thinking beings. The anomaly clearly avers that we cannot intrude in the universe, about what is occurring in it and by which way it will modify. Actually, the upshot is happened. We may try to find out if the event links to the backdrop. The quest evokes the "cosmos" as order (opposed to "chaos"): the apparent "matter/energy" changes, since the tied "information" modulates its current existence. We are part of the all, driven by the same directives and sharing the on-the-go alterations [1]-[5]. With absolute readings, the picture has twin construals:

- Dualism: the material reality is ruled by the transcendent (godlike) order;

- Monism: the matter contains total control into its immanent information. 
The existence of the "natural order" with laws and cause/effect bonds is peculiar hypothesis; it allows reconsidering the man/universe context, making plausible the existence of connections. On absolute basis, we refer to God's pledges or to Cosmos' ties, with upper or inner driving schedules. The situations are more or less strictly programmed, and we only have to look at residual chances, if any, we have to adjust front-end details. The $a b$ solute (dualism or monism) orders possibly exist [6]-[10]: open query is the link to the men's knowledge. On conditional basis, we imply "life" and "intelligence" singularities, gene evolution to agentive self-reproduction and meme fruition to rational decision keeping; the on-the-go setups are not already planned, but the human freewill makes us responsible for our prosperity or distress.

The existence of the universe's "natural laws" and alleged exceptions (miracles or singularities) is "faith" with wannabe believability, providing a way to draw from the context, hints on how interpreting the above supposed absurdity. The absolute construal is hard to justify, unless the perfect link of human adventurous progress and recognised cosmos' "information" are proved. The contingent one has fuzzy boundaries, since it develops at conditional worth, and only weedy ties are progressively required. The recalled elucidations express as "anthropic principle" of the human civilisation.

\section{The Civilization Sources}

The study of the mankind civilisation shows the earth peculiarities: biology, with the copy autonomy of the living beings; cognition, with the emulation and reasoning abilities of the men. In our short tip-offs, the idiosyncrasies are linked to an imaginable strong anthropic principle, Figure 1, which states that the universe ruling "information" includes exact natural laws, which make the men's mission towards civilisation already assigned. The upshots are absolute truths, because the upper veracity assigns the undertakings, or because the inner categorist force accredits the pace wise advancements [11]-[15]. The unconditional certainty of the detected natural laws is "faith", with debatable might, at least, if we acknowledge the entropy decay within the same frame, positively, affecting "matter" and "information" by native autocracy.

When absolutism is dropped, the faith totters. Moreover, the derivation of the intelligence from the life is not yet proved by causative bonds. So we switch to the weak principle, Figure 2, stating that the inner logic could develop along a relational path, even if strict causal links cannot be proved [16]-[19]. Indeed, evolution and fruition traits, biology and cognition, are mankind centred, rather than on upper or inner certainties, thought to be already present in the universe. The statement is equivalent to say that the civilisation is remarkable accomplishment not because of our "faith" that rigorous natural laws exist and we have access to them, but because men exist and share the talent making feasible knowing the earth's trends, once life and intelligence provide the starting conditions to "biology" and to "cognition".

The assent on the weak form takes strength if the practices of the strong rituals are reliably agreed. In the past, the anthropic principles deserved focused cosmology investigations, showing the relevance of the "invariants", from the gigantic modes of the general relativity, to the tiny events of the quantum mechanics. Lately, the genome disclosure tells that pertinent "information" details pre-exist, and the detected rules are proper foundation of the biology world, perhaps, by gene evolution up to relational abstract cogency. If the civilisation has roots in the strong "anthropic principle", the continuance shall trust prayers that touch the godlike ruling or chances already included in the cosmos' odds and ends. If the onsets are in the weak one, the men's intentional planning

- THE MEN BENEFIT OF ALL THE OPTIONS, TO EXPLOIT THE TWIN ODD LIFE AND INTELLIGENCE WHEREWITHAL;
- SIDE COROLLARIES ARE: THE INTELLIGENT DESIGN OVERSEES THE ALL, TO FASHION THE OBSERVERS; THE
OBSERVERS ARE NECESSARY, BEING THE GOAL OF THE DESIGN; THE UNIVERSE REPEATS TO CONCLUDE THE
DECLARED TWO ODDITIES, AS OUR EARTH HAS ACKNOWLEDGED DISTINCTIVENESS (WITH OR WITHOUT
LIFE/INTELLIGENCE REITERATION).

Figure 1. The strong anthropic principle.

- THE MANKIND IS END-RESULT OF ODD EVENTS, THOUGH, WARRANTING CONTINGENCY COHERENCE.

- THE RECOGNITION OF THE PHYSICAL MODELS IMPLIES COORDINATED HAPPENINGS, BECAUSE THE TWO RESTRICTIONS EXIST: 1) TO MAKE FULFILLED SELF-REPRODUCTION LIFE AND COGNIZANT INTELLIGENCE; 2) TO APPORTION PROPER SEQUENCE AND EXTENSION OF ACCOMPLISHMENTS, CONFIRMING THAT THE TWO EVENTS ARE ALREADY HAPPENED.

Figure 2. The weak anthropic principle. 
alters the prospects, depending on how the management of the surrounds and the resources is undertaken. The alternative may not be so drastic: partial possibilities for betterment or worsening could be left, with the absolute construal; restrained capabilities are perhaps in men's accessibility, with the provisional one [20]-[26]. The explorations that follow advice keeping strong and weak readings as parallel signs that in the mankind existence and dispositions belong to "natural order": the facts authorise thinking that the future could be programmed with a special anthropic weight.

The anthropic principles are, thus, backdrop to expect the continuance of sustainable growth, based on relatable "information" niceties, processed by human minds. The tangible elements of the progress embed the relationships with the inert/alive surroundings and with the interpersonal dealings. Both entail entropy falloffs. The intangible elements ensue from creative additions: the "culture" and "ethics". The former gives the know-how of technology revolutions, inferred from "natural laws"; the latter bestows principles for managing "collective orders", via social breakthroughs, promoting wise "human laws". The progress has to provide life-quality artificial improvements, creating value added by the transformation economy applied to the natural resources, and the socio-political arrangements, modifying the extant collective assemblies by interpersonal assets.

\section{Social Breakthrough Aids}

The socio-political arrangements are promoted by the men rational inventions, e.g. the languages, to communicate; the trade, to resources' exchange; the legality, to steady governance. Cosmos' information stays, possibly, in background; human arts imply artificial aids. Value added has pooled qualities, involving knowledge creation, shaping "technical capital", and assessment backups, outfitting the "financial capital".

The relational cogency replaces the causal linkage of absolute laws; the outcomes may be depicted by net ties, using allied faint contexts to show the usefulness of "principles", which stimulate improvement, Figure 3, even while only aposteriori mind versions are invented and, subsequently, checked on the results [27]-[30].

The relational cogency (in lieu of causal bonds) is pace wise acknowledged, when upshots are there; in addition, the planning requires comparing alternatives, holding the freedom of the on-progress decision-keeping, to adapt the course, with removal of picks, which happen aiming at noxious ploys. That construal imputes the "progress" to the men intelligence, say, to the strange occurrence, creating the "mind", and organising the related world of knowledge, models and theories. The reading encourages resorting to anthropic principles, since we recognise the worth of the civilisation, and we conclude that the happenings actually develop, with, however, complimentary weights difficult to conceive, unless the manmade side is preponderant. From the history, we know that the goings-on promote the "progress" of mankind by:

- Social breakthroughs: the added value builds on the "collective order" structuring;

- Technology revolutions: the know-how buoys innovative material transformations.

The synthetic improvements begin from the relational abilities, never found in living beings, different from men. They are credited to the "intelligence singularity", an inexplicable event, creating social skill, i.e.:

- Communications by idioms, after the parental teaching/training of children;

- Trade by barter/market, aimed at the interpersonal fulfilment of necessities;

- Legality by sovereign institutes, assuring governance by nation-state's bounds.

In lieu of absolute, the civilisation denotes contingency or functional virtues. The progress is relative fact; its unassailability has to face enduring extra challenges, in view to manage:

- The "intruding innovation", as for the technology and the social alterations;

- The "growth sustainability", as for the surround depletion/pollution fallouts.

The "intruding innovation" is permanent pride of mankind, thinking to play a mission in the universe. The "growth sustainability" is impending threat of the new millennium: the ecology globalisation imposes the necessity of a new revolution, because breakthrough alterations shall affect the course of the advance. This is optimistic viewpoint: in provisional reality, nothing is certain: the engineer's bent obliges accepting defies and challenges.

RELIANCE IN ABSOLUTE PRINCIPLES: THE REALITY ENJOYS A PRIORI ENTIRELY PRE-SET MODELS TRANSCENDENCE: GOD ROUTING BY TRUTHS -IMMANENCE: DETERMINIST FINAL OUTCOMES RESORT TO CONTINGENT PRINCIPLES:THE MODELS ARE A POSTERIORI MIND INTERPRETATIONS TANGIBLE AIDS: TECHNOLOGY REVOLUTIONS -INTANGIBLE AIDS: SOCIAL BREAKTHROUGHS

Figure 3. The absolute and contingent contributions. 
The agrarian and industrial revolutions focused, in the past, biology/genetics and thoroughness/cognizance to widen gains and riches. Thereafter, sustainability strops to be practicable if the two biology and cognition peculiarities do not support the man-planned transformations, yielding worthy and safe add-ons. The over-consumption/pollution figures compared to the on-going recovery/reclamation trends show coming limits to the potential growth. The changeovers require:

- The technical skills: measures granting recycle and reintegration upshots;

- The social consistency: collective orders aimed at safe eco-management.

The expected revolution, resorting to engineering standpoints, shall involve the supply chain visibility, with the mentioned effects and controls. The man made improvements necessitate economic evenness and organisation suitability of the value added production, allocation and enjoyment; coherent outfits might entrust the "sustainable corporation" solutions, endowed with updated power, regulation and jurisdiction. The pointed-out answer shall, necessarily, be discussed on its contingent worthiness, looking after coherent widening of agrarian and industrial revolutions, with apt weight to thoroughness/cognizance import. The cognitive revolution explicitly makes use of robot technologies and applications, with recourse to artificial life-and-intelligence tools as on-process improvements, purposely devised and implemented by men, with pace-wise check of their merit and confidence [31]-[34]. The material resources are precise input in men's plans. The cosmos' information supplements are blurred in the men's knowledge, without explicit mention of the allied contingent worthiness, replacing the undetected absolute consistency. The frugal innovation is the cognitive revolution fallout, combining artificial life-and-intelligence tools to spare tangibles, since the intangibles are enhanced auxiliary.

\section{The Men-Centred Depiction}

The progress characterizes by the plus-value, created compared to wilderness, i.e. fit "capital assets", made available, exchanged or shared. "Capital" is odd word, from caput (head), as the asset is personally allotted; the ownership needs law frameworks and these require on-duty authorities. The oddness entails "intelligence" synthetic construal, say, the culture and ethics artefacts, with tied communication (language) and market (trade) inventions. The "capitalism" involves human, natural, technical and financial assets, to appraise the personal and communal riches, lumping, each time, the evaluations within legal metrology schemes. The valued riches are implicit (collective order, etc.) or explicit (workforce pay, etc.), demand intellectual abstraction and expect jack-of-all-trades conversion. The "human capital", Figure 4, is synthetic aid to create "collective orders", assuring the structured governance of the involved citizens. The issue profits by well-established approaches, keeping implicit plus-value [35]-[39].

The "collective order" political ways lead to "nation-states" in competition: the efficiency differences are reason of supremacy, backed by top-down structures, which use welfare inner solidarity and alien exclusion measures. The "closed union" is historically priced achievement, managing identified "communities", into which hierarchy links (with godlike backing) or conformity bonds (due to racial evenness) are supposed pre-existent. Both are absolute truths, based on upper either inner "information", depending on "transcendent" or "immanent" construal of the surrounds, according to "dualism" or "monism" readings. The Enlightenment has upsetting ties with upper either inner "information": God is dominance belief; inherent causal frames turn occurrences in necessities. The "laws" may not have upper or inner pre-setting; they initiate from the human intelligence singularity; they are relational construal, due to the rational interaction of men, which enjoy the freedom of building "culture" and "ethics" and of choosing know-how and rulings. In the sketch, it is better to get rid of the upper or inner pre-set "information", replaced by the "human knowledge/morals", i.e. creative information or conjectured laws. The political and civic choices are aids, Figure 5, used to justify or to factually organise the current "collective orders" [40]-[44], rooted in the achieved "human capital".

The "open union" is liberalism alternative, once believing that the law has bottom-up authenticity, built by the civic worth of the individual citizens, but not top-down ruled by sovereign political orders, rooted in baseless

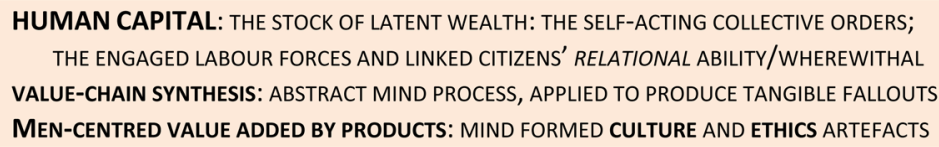

Figure 4. The human capital: main features. 


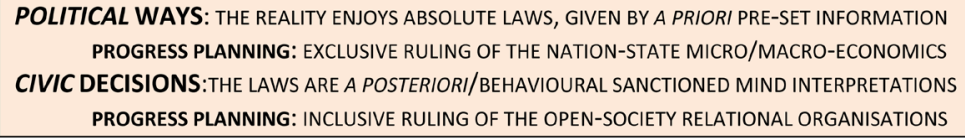

Figure 5. The collective order governance.

beliefs or arbitrary reliability. Conscious freedom welcome changes, because "stability" does not imply conservatism, rather adaptability. Flexibility allows comparing choices and selecting fittingness, each time improvements are recognised realistic. If ecology is coming challenge, the "sustainable corporation" could develop with bottom-up coherence, by inclusive procedures, once the man-planned transformations satisfy the eco-consistency precepts [45]-[48], using blow-up measures and a posteriori checks. The hierarchy arts, however, remain standard options until when a priori "sovereignty" is used, trusting in God's grace, or in race's homogeneity principles.

Moreover, the "human capital" has also been involved by explicit plus-value creation. The human work, out of slavery, shall be assessed and paid. With industrialism, the workforce plays basic roles, to specify the process effectiveness; the robotics is supposed to replace to great extension the handling and manufacture tasks, once correct programmes and operation systems are made available. These topics converge in the instrumental/anthropoid robot conception and assembly. The change is the removal of on-line operators; the substitution by robotic courses offers chances of expanded processes, if, however, the "intelligence" self-reliance is made operative.

\section{Worth Synthetic Management}

The depiction is man centred: the motor of all the happenings starts involving the "human capital". The "financial" or the "technical" capital arrangements need abstract practices, before giving independence to the linked worth accretions. The former, actually, is old invention, resorting to the "money", the synthetic items with officially allocated conventional values. This way, market supplants barter, using finalised items, wittingly defined by their allotted worth. The latter is recent acquisition; it uses "concession" and "patent" recognition, to extract worthy contrivances and procedures with protected safeguards [49]-[55]. The recalled rituals end in tangible assets, Figure 6, even when virtual or provisional worth is handled.

The worth allotted to mind practice results is sovereignty's buoyed. The "unification" of economic into political orders narrows the money tasks; the "role severance" spreads multiple financial flows. Besides:

- The "economic managing" fosters trade control by top-down authority schemes;

- The "financial gaming” bets on default/bankruptcy risks, baked by Ponzi’s traps.

Legality stays government task, even when the marginal influence of given nation-states penalises the citizens face to transnational speculation. The "financial gaming" manipulates sovereign treasury bonds; the taken risk remuneration builds on derivative's gismos, making profit by buying/selling structured products, developed following the "IBG|YBG (I'll be gone/you'll be gone)" rule. The subverting effects, at first, may limit to weaker partners with profit to stronger ones, basically, obtained stockpiling prosperity rooted in virtual wealth. The financial gaming at firm's range bets on bankruptcy, at country's on default. In the new millennium, the virtual wealth flow is becoming monstrous (it make seem negligible the actual trade flow!). The country's default is lucrative wager, until stability totally ceases.

The top down legality schemes are similarly used for the intellectual items' management by:

- Separation between "invention" and "inventor", with suitable rewarding of the latter;

- Explicit recognition of "intangibles", defending the discovery ownership and trading.

The breakup at split-sovereignty range is awkward fact, entitling local tenures and incomes; however:

- The person fulfils qualified intellectual activity and shall be correctly rewarded;

- The overall society shall have access to innovation, without outside restraints.

The pioneers should be qualified the global village over (out of each country); the mankind cannot be deprived enjoying advances, without synthetic splits and lawfulness orders, dividing citizens from aliens. It is, however, clear that many value added routes exist. Usual analyses include: the primary (farming, mining, etc.), secondary (manufacturing. etc.), tertiary (services, etc.) or also quaternary (entertainment, etc.) twigs, under governmental rule; they promote the gross domestic product, GDP. The administrative artificial divisions are men's peculiarity: the civilization goes further on knowledge and ethics artefacts; the new tracks presume the possibility of creat- 


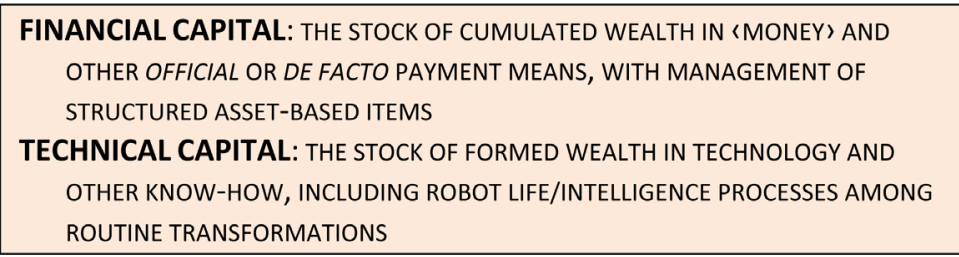

Figure 6. The financial/technical capital delineation.

ing extended "technical" capital, via robotics. Compared to the "financial" assets, the official management is just formal; both, however, require inventing “civic decisions" to replace the "political ways” of the debated sovereignty concepts [56]-[59], as officialdom imprint.

The robot-driven cognitive revolution, if the above analysis is correct, is necessary, not sufficient option. We need to look at technology expansion towards artificial life/intelligence contrivances, using gene-driven and meme-ruled innovations. We shall, though, never forget that the picture deals by "human knowledge", built on contingency. Our forecasts are destitute of absolute worth: further pace wise checks are necessary, and the growth will necessarily stop, if the "entropy law” is correct. Still, robotics, from mere automation solutions, can turns to integrated programmes, making possible further developments towards knowledge engineering zings. The statement is maybe somehow crazy, but it does not denote bypassing “entropy law”. The robot-based cognitive revolution matures on strictly contingent relative logics, if the weak anthropic principle is accepted as standard references and the frugal innovation bypasses as far of possible tangibles' depletion by artificiallife-andintelligence tools.

\section{Tangibles' Safe Running}

The man centred depiction, today, mostly forgets that the intangible mind inventions are essential, but the civilisation develops in the material reality. Indeed:

- There is no life without consumption: the overall entropy balance is positive;

- There is no wellbeing without consumables: the growth swallows-up hoards.

The remarks apply to the earth; but, our science tells that "entropy” is cosmos' quality. The intangibles focus our attention, as if the civilisation could steadily last. The attitude follows the "collective order" line, via socio-political hegemony, towards sovereign legality and total rights. Fundamental issues are:

- The absolute possession of the items, allowing annihilation freedom: resperitdomino;

- The controller legitimacy for the allocation of monopolies, tenures and/or ownerships.

The tangibles are entitled by the "nation-state", as private (capitalism) or public (communism) goods; the growth is factually top-down ruled, as if the "sovereignty" (say, split-sovereignty) allows complete free-availability of the earth sources. Until today, the value series profit of makeover and management options:

- The "agrarian produce” stage, purposely selecting sets of biotic samples/cycles;

- The "industry product” span, manufacturing useful objects, from raw materials;

- The "business stability" rank, contriving fair and effective trade establishments;

- The "law cohesion" class, ratifying right/duty balanced governance institutions.

The ecology globalisation shows that the "sovereignty" is blasphemy, if private or public ownership is unqualified. The qualification is out of the "nation-state" privileges; it is global village prerogative. The on-the-go supply chains need to compute the plus-value, including the "natural capital", Figure 7, in the balance. The changeover cannot accept absolute trends; the contingency appraisals are man centred, and extension entails recycle/remediation upshots, by "to rematerialise" and "to dematerialise" measures [60]-[64].

The "sustainable corporation" is factual big society solution, with blow-up "legality" management, via settlement councils' monitoring and certifying bodies' control. The inclusive route profits by decentralised operators and devolved liability entrepreneurship. The value steps include:

- To design legal manufacture cycles, under a resource manager liability;

- To avoid dumping, planning closed flows, chaining outputs into inputs;

- To invent official supply chains, under controlled stuff/energy feeding;

- To deliver "functions" that replace "goods", under an unified overseeing;

- To furnish lifecycle service, fulfilling the maintenance and refurbishing;

- To perform reverse logistic duties, within mandatory regaining targets. 


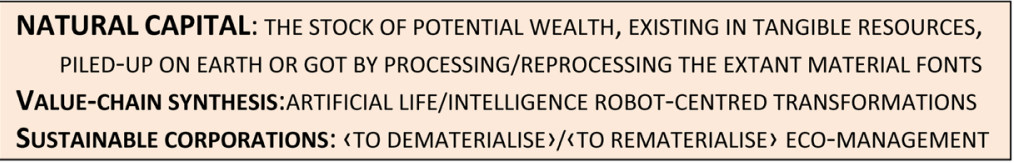

Figure 7. The natural capital: main features.

The recycle/remediation goals, typically, require suited assessments, e.g. using the "typus-metrics", Figure 8, showing the in-progress depletion. The "natural capital" is necessary entry of the XXI century concocting plans. The men's means shall include reverse logistic options, with the twin purpose to widen intangibles' roles and to recover tangibles' resources. From technical standpoints, the "cognitive revolution" defines in terms of robot technologies. Yet, these are not sufficient to acknowledge how the needed changeovers can be empowered, because the current socio-political arrangements, presuming sovereign (private and public) management of the "natural capital", lead astray, with the ownership-like practices. To look after growth sustainability prospects, the present analyses move from the "anthropic principles", awkward way to assess the coherence of the civilisation facts. These lead to believe in "natural law" actuality and "human law" rashness up to "collective order" reality: can we trust the one or the other or the two?

\section{Growth Aware Scheduling}

The last question involves the connection between the cosmos "information" and our "knowledge". The agreement on the relational view is clear, if we pick the "collective order" governmental alternatives:

- Absolute authenticity by "Grace of God" or "Nature Selection" institutes;

- Contingent legality by "Constitutional Sovereignty" or "Big Society" keys.

It is much less obvious, when we look at the "natural law" actuality. The "theory of everything" seems saying that the basic universe "information" is accessed: we can trust the science models, at least, fitting to the falsification checks. Moving from the culture, to the ethics artefacts, the abstract socio-political guesses are similarly trustful, including sovereignty dependability, from which averring human law power. So, the civic vs. political choices, Figure 5, oppose contingent to total legitimacy, by substitute tracks:

- The "constitutional agreement" has top-down binding order routine construal;

- The "big society" alternative goes bottom-up, leading to marshalled fittingness.

The second track is, today, unknown; it eludes the inconsistency of the first. The mankind relational context builds on the "open union" inclusive patterns, avoiding the exclusive stages of the "closed union". Then, by liberalism, it includes "altruism" as basic "rationality" wherewithal, when eco-protection becomes compulsory global village constraint, even when the split-sovereignty clearly asserts dissimilarities. The "sustainable corporation" is straightforward solution, once bringing-in standards, such as:

- The settlement of the legal utilisation of intangibles, and of their lawful protected use;

- The official extension at the globalvillage range of the technology rights and fallouts;

- The socio-cultural acceptation of the cognitive evolution, with its artificiallife options;

- The socio-political updating, consistent with the extant ecology globalisation conditions.

The "sustainable growth" entails the existence of rational policies granting behaviours' eco-consistency. The absolute (transcendent) dualism and (immanent) monism depictions link to matter/information laws totally subjected to entropy decay: we may implore God for miracles, or trust in Nature for dreams; only contingency suggests rolling up sleeves, with faith in clever tricks. But this is not enough, unless the same decision embroils all the earth people. "Constitution agreements", each time, involve identified "collective orders"; they cannot encompass people not pinpointed by the specific covenants; the procedure leads to "closed union" makeups, defined "nation-states". These are political setups, under allotted governance, and oppose to parallel ones, once competition consents discriminating winners and losers. The option is "social Darwinism": it uses gene selfishness law, marginalising unfit units (genes, individuals or countries); it, as well, avoids rational policies with behaviours' eco-consistency, until the overall catastrophe [65]-[70].

The "big society" key, possibly, is option: the global village "rational" policies are "cognitive revolution" quirk; the "sustainable corporation" is standard way out, if a set of simple rules apply, e.g.:

- The right of the discoverers to hold the "individual" ownerships of ideas and tied applications;

- The recognised protection from the "society", to obtain proper reward, by a patent mechanism; 
- (TYPUS) TANGIBLES YIELD PER UNIT SERVICE

- THE APPRAISAL COVERS THE TANGIBLE SUPPLY CHAIN, FROM THE PROCUREMENT TO THE RECOVERY; EACH DELIVERED PRODUCT-SERVICE HAS LINKED FIGURES, ASSEMBLING RESOURCE DEPLETION AND FALLOFF, REQUIRING 〈TO REMATERIALISE)/〈TO DEMATERIALISE) REMEDIATION.

Figure 8. Example over-depletion/pollution metrics.

- The "official" decree and legitimacy of correct (safe) innovation, matching private/public roles;

- The "segment" specification of the innovation, deciding on the allowed and forbidden tenancies;

- The lawfulness of allocated "monopolies", dispossessing other people from their free enjoyment;

- The legitimacy of technology preserves, sanctioning approved "precaution principle" guidelines.

Until today, the legality standard application without "nation-state" was difficult to conceive. Now, the split-sovereignty, with highly indebted marginal countries, requiring tax systems destroying around $50 \%$ of the gross domestic product, GDP, to survive, has dug its grave. It becomes hard to justify that such amount of the national wealth is needed to pay for running local administrations, face to questionable collective results. The state merging is useful, if the costs are deleted and spread out at the "big society" institution, ending at the global village range. The inter-state competition, when the ecology globalisation establishes is expedient, if survival limits to a subset of groups/countries and on condition that the struggle does not drastically worsen. The reality, indeed, is critical. The "ecology globalisation" is current idiom stating that the depletion and pollution figures of the extant makeover are untenable: the future progress stops; the effects are global, i.e. they distress the whole earth with linked inhabitants. The overall situation is, still, undecided by the public opinion: it requires deepening and better understanding. The present note points out that "big society" keys have to be devised, because the Darwinism of the split-sovereignty competition cannot anymore support the ecology requests.

\section{Conclusions}

The analyses on the "ecology globalisation" start far away, discussing the civilisation event. Surely, it is totally negligible, if it is compared to the actually detected universe. If we have faith in transcendence roots, we shall hope in miracles; if it is in immanence ones, we shall wait and see, being hard choosing among cicada oblivious carefreeness or ant aware frugality tale. The survival wars are, as well, striking choice to remove as many end users as possible, remaining favoured punters. Nonetheless, the civilisation event is tricky fact: via the "anthropic principles", it seems to hint the third path, building persistence by clever designs, i.e. the "cognitive revolution", applied to the mankind global village over. Even if we bet, it is worth studying its feasibility: the challenge requires a totally new "social breakthrough"; the analyses offer preliminary hints to say if the third way is viable [71]-[74], both via technology innovation and social construal.

The progress is characterized by the plus-value, judged against wilderness, created, exchanged or shared, i.e. by fit "capital assets". "Capital" is odd word, from caput (head); assets are personally allotted; the allocation needs law backdrops and these require on-duty authorities. The oddness involves "intelligence" artefacts, namely, culture and ethics items, with the linked communication (language), market (trade) and legality (sovereignty) inventions. The extant progress entails human, technical, financial and natural assets to weigh up the personal/communal chattels, grouping the evaluations into legal metrology schemes. The appraisal is implicit (collective order, etc.) or explicit (workforce pay, etc.); it claims intellectual construct and expects jack-of-alltrades conversion. The synthetic readings and lawfulness orders are men-centred conventions, with sovereignty hegemonic versions, dividing citizens from aliens, and using formal blends by GNP, gross national product and grades. Yet, this is manmade picture rather than absolute truth.

The management constructs are questioned: “communism” opposes to "capitalism”, replacing private by public ownership, under a ruling nomenclature. In fact, friendship, contractual and political partition, just entail the relational, pledged or officialdom types, but the behind ownership credentials keep total bias from individuals to assemblies, always, "res perit domino" and this allows entire private/public control on the allocated "capital assets". In truth, with the "natural capital", the transformation plus-value links to entropy, that is, it suffers material scrap/decay at the overall cosmos range.

At the "ecology globalisation", the value adds builds by personal/collective task and under related responsibility. Ownership has to be replaced by tenure, notably, for material stuffs, with accountability at global village range and liability at recovery/remediation onus. The sustainable growth is bet, needing the "cognitive revolu- 
tion" (after the agrarian/industrial ones). The innovation is based on robot technologies: artificial intelligence, aimed at "to dematerialise" processes, and artificial life, aimed at "to rematerialise" products. The technical advance goes together with the new social breakthrough, replacing political supremacy and sovereignty statuses, by unified global village authority. The devised changeover looks at "big society" arrangements, enabled through "sustainable corporation" management structures, decided by "settlement councils", overseen and controlled by "certifying bodies". The exclusive closed societies are switched to new inclusive open unions, empowering "altruism" interpersonal acquaintance and social cooperation, further to trade and administrative roles, under "hyperdemocracy" jurisdiction.

The "cognitive revolution" way is hypothesis already discussed, notably, on the technology prospects of the robotic developments. The new revolution is, surely, impressive, but the technical innovations will add in the current life of everybody, smoothly altering the interpersonal habits. The in parallel necessary social "global breakthrough" is thought more imposing, because totally out of the extant traditions and practices. The changeover, from the selfish gene evolution to the altruist meme fruition, is oddity, deserving attention and suggesting serious considerations on the "rationality" wherewithal. The connected talent cannot enjoy absolute (transcendent or immanent) worth: it may be contingent ability, to be explored and exploited by the mankind, within the earth's current context, until when the "ecology globalisation" shall stop the men's chances.

\section{References}

[1] Bellone, E. (2011) Something out There: How the Brain Creates Reality. Codice Edizioni, Torino.

[2] Ferguson, N. (2011) Civilisation: The West and the Rest. Allen Lane, London.

[3] Menary, R. (2011) The Extended Mind. MIT Press, Cambridge.

[4] Noë, A. (2009) Out of Our Heads, Why You Are Not Your Brain and Other Lessons from Biology of Consciousness. Hills \&Wang, New York.

[5] Viale, R. (2014) Methodological Cognitivism: Cognition, Science and Innovation. Springer, Berlin.

[6] Flanagan, O. (2012) The Really hard Problem Meaning in a Material World. MIT Press, London.

[7] Michelini, R.C. (2008) Knowledge Entrepreneurship and Sustainable Growth. Nova Science Publishers, New York.

[8] Sennett, R. (2012) Together: Rituals, Pleasures and Politics of Cooperation. Allen Lane, London.

[9] Stewart, J., Grapenne, O. and Di Paolo, E. (2008) Reflections on the Bodily Basis of Consciousness. MIT Press, Cambridge.

[10] Wichert, A. (2013) Principles of Quantum Artificial Intelligence. World Scientific, Singapore. http://dx.doi.org/10.1142/8980

[11] Agar, J. (2012) Science in the Twentieth Century and Beyond. Polity, London.

[12] Holt, J. (2012) Why Does the World Exist? An Essential Detective Story. Norton, London.

[13] Pievani, T. (2011) Unexpected Life. Cortina Editore, Milano.

[14] Targowski, A. (2008) Information Technology and Societal Development. IGI Global Publishing, Hershey.

[15] Wilson, E.O. (2012) The Social Conquest of the Earth. Norton, New York.

[16] Larson, B.A., Ed. (2009) Sustainable Development Research Advances. Nova Science Publishers, New York.

[17] Manna, F. (2006) A Peculiarity of the Human Species: Language for Symbols. Cicchetti, Isernia.

[18] Rovelli, C. (2014) The Reality Is Not as It Appears. Raffaello Cortina, Milano.

[19] Thye, R. and Lawler, E.J., Eds. (2009) Altruism and Pro-Social Behaviour in Groups. Emerald Book, Bingley. http://dx.doi.org/10.1108/S0882-6145(2009)26

[20] Beltz, C.R. (2010) The Idea of Human Rights. Oxford University Press, Oxford and New York.

[21] Johnson, S. (2013) Future Perfect: The Case for Progress in a Networked Age. Allen Lane, London.

[22] Michelini, R.C. (2011) Knowledge Society Engineering: A Sustainable Growth Pledge. Nova Science Publishers, New York.

[23] Ossicini, S. (2012) The Universe Is Made of Stories, Not Only of Atoms: A Brief History of Scientific Fraud. Neri Pozza, Vicenza.

[24] Teuteberg, F. and Gomez, J.M., Eds. (2010) Corporate Environmental Management Information Systems. IGI-BSR, Hershey. http://dx.doi.org/10.4018/978-1-61520-981-1

[25] Yanofski, N.S. (2014) The Outer Limits of Reasons: What Science, Mathematics and Logic Cannot Tell Us. MIT Press, 
Cambridge.

[26] Deaglio, M. (2004) Postglobal. Laterza, Bari.

[27] Scipione, A., Ed. (2012) Focus on Biomimetics Research. Nova Science Publishers, New York.

[28] Solove, D.J. (2004) The Digital Person: Technology Privacy in the Information age. New York University Press, New York.

[29] van Leeuven, J., Gopalakrishnan, K. and Brown, R.C., Eds. (2010) Sustainable Bioengineering and Bioproducts. Springer, Berlin.

[30] Forey, D. (2004) The Economics of Knowledge. MIT Press, Cambridge.

[31] Michelini, R.C. (2009) Robot Age Knowledge Changeover. Nova Science Publishers, New York.

[32] Silvius, G. and Tharp, J., Eds. (2013) Sustainability Integration for Effective Project Management. IGI Global Publishing, Hershey. http://dx.doi.org/10.4018/978-1-4666-4177-8

[33] Smolin, L. (2013) Time Reborn: From the Crisis of Physics to the Future of the Universe. Allen Lane, London.

[34] Atwood, M. (2008) Playback: Debt and the Shadow Side of the Wealth. House of Anansi Press, New York.

[35] King, S. (2013) When the Money Runs Out: The End of Western Affluence. Yale University Press, New Haven.

[36] Legrenzi, P. (2011) First Lesson of Cognitive Science. Laterza, Bari.

[37] Mullah, S. (2013) The Selfs and Its Shadows, Oxford University Press, Oxford.

[38] Walter, C. (2013) Last Ape Standing: The Seven Million Year History of How and Why We Survived. Walker \& Co., New York.

[39] Geary, P.J. (2002) The Myth of Nations: The Mediaeval Origin of Europe. Princeton University Press, Princeton.

[40] Heineman, M. (2009) Czechoslovakia: The State That Failed. Yale University Press, New Haven.

[41] Klein, N. (2009) No Logo. Forth Estate, London.

[42] Powell, W. and Clemens, E., Eds. (1998) Private Action and the Public Good. Yale University Press, New Haven.

[43] Targowski, A. (2013) Harnessing the Power of Wisdom: From Data to Wisdom. Nova Science Publishers, New York.

[44] Baldwin, P. (2014) The Copyright War: Three Centuries of Trans-Atlantic Battle. Princeton University Press, Cambridge. http://dx.doi.org/10.1515/9781400851911

[45] Davies, N. (2012) Vanished Kingdoms: The Rise and Fall of States and Nations. Viking, New York.

[46] Navarra, P. and Bavetta, S. (2012) The Economics of Freedom: Theory, Appraisal and Policy Implication. Cambridge University Press, Cambridge.

[47] Koo, R. (2009) The Holy Grail of Macroeconomics. Wiley \& Sons, London.

[48] Rajan, R., Myers, J.J. (2010) Faulty Lines: How Hidden Fractures Still Threaten the World Economy. Princeton University Press, Princeton.

[49] Cowen, T. (2011) The Great Stagnation. Penguin Pub., New York.

[50] Mason, A.C. (2012) Bioremediation: Biotechnology, Engineering and Environmental Management. Nova Science Publishers, New York.

[51] Michelini, R.C., Frumento, S. and Razzoli, R.P. (2010) The Duty-Split Approach in Robotic Surgery. Nova Science Publishers, New York.

[52] Quintela Varajao, J.E., Cruz-Cunha, M.M., Putnik, G.D., Trigo, A., Eds. (2010) Enterprise Information Systems. Springer, Berlin.

[53] Sandel, M.J. (2012) What Money Can’t Buy: The Moral Limits of the Market. Farrar, Straus \& Giroux, New York.

[54] Zingales, L. (2012) Capitalist Manifesto: Refound Capitalism in Favor of the Citizen. Rizzoli, Milano.

[55] Chong, N.-Y., Ed. (2013) Networking Humans, Robots and Environments. Bentham Books, Sharjah. http://dx.doi.org/10.2174/97816080573131130101

[56] Ilmanen, A. (2011) Expected Returns: An Investors' Guide to Harvesting Market Reward. John Wiley \& Sons, Hoboken.

[57] Rubenfeld, J. and Chua, A. (2014) The Triple Package: What Really Determines Success. Penguin Press, New York.

[58] Ward, T.B., Finke, R.A. and Smith, S.M. (1992) Creative Cognition: Theory, Research \& Application. MIT Press, Cambridge.

[59] Ehrenfeld, J.R. (2008) Sustainability by Design. Yale University Press, New Haven.

[60] Goti, A., Ed. (2010) Discrete Event Simulation. SCIYO Pub., Rijeka. http://dx.doi.org/10.5772/257 
[61] Lovelock, J.E. (2009) The Vanishing Face of Gaia. Allen Lane, London.

[62] Michelini, R.C. (2012) Society Progress Evolution: Sustainability and Responsiveness. Nova Science Publishers, New York.

[63] Tanuro, D. (2011) The Impossible Green Capitalism: Climatic Warming and Reasons of Eco-Socialism. Ed. Alegre, Roma.

[64] Hyman, L. (2011) Debtor Nation. Princeton University Press, Princeton.

[65] Marcus, J. and Flannery, K. (2012) The Creation of Inequalities: How Our Prehistoric Ancestors Set the Stage for Monarchy, Slavery and Empire. Harvard University Press, London.

[66] Scipione, A., Ed. (2012) Focus on Biomimetics Research. Nova Science Publishers, New York.

[67] Taylor, F. (2013) The Downfall of Money: Germany's Hyperinflation and the Destruction of the Middle Class. Bloomsbury, London.

[68] Tomasello, M. (2008) The Origins of Human Communication. Raffaello Cortina Ed., Milano.

[69] Xie, M. (2012) Fundamental of Robotics: Linking Perception to Action. Imperial College Press, London.

[70] Latouche, S. (2007) Small Treaty on Serene Decay. Mille et uneNuits, Paris.

[71] Michelini, R.C. (2016, in Press) Cognitive Revolution Quest: Human Civilization Prospects. ARACNE Ed., Roma.

[72] Putnik, G.D. and Cunha, M.M., Eds. (2005) Virtual Enterprise Integration. IDEA Group, Hershey. http://dx.doi.org/10.4018/978-1-59140-405-7

[73] Schwager, J. (2013) Market Sense and Nonsense: How the Markets Really Work (And They Don't). John Wiley \& Sons, New York.

[74] Zweig, J. (2007) Your Money and Your Brain. Simon \& Shuster, New York. 